\title{
Discrepancy and spatial grouping of individual potential among Kebumen Ongole Grade cattle farmers in Kebumen Regency
}

\author{
M. Sugiarto ${ }^{1, a}$, S. Nur ${ }^{1}$, O.E. Djatmiko ${ }^{1}$ and S. Gayatri ${ }^{2}$ \\ ${ }^{1}$ Faculty of Animal Science, Jenderal Soedirman University, \\ Karangwangkal, Purwokerto Utara, Banyumas 53123 - Indonesia \\ ${ }^{2}$ Faculty of Animal and Agricultural Sciences, Diponegoro University, \\ Tembalang Campus, Semarang 50275 - Indonesia \\ *Corresponding E-mail: zoegic@yahoo.com
}

Received December 11, 2018; Accepted February 24, 2019

\begin{abstract}
ABSTRAK
Penelitian ini bertujuan mengidentifikasi perbedaan potensi individu peternak Peranakan Ongole (PO) Kebumen dan menganalisis pengelompokan wilayah pengembangan sapi PO Kebumen berdasarkan potensi individu peternak. Penelitian dilakukan menggunakan metode survei pada peternak sapi PO Kebumen di 6 kecamatan yang merupakan pusat pengembangan sapi PO Kebumen (Kecamatan Puring, Petanahan, Klirong, Mirit, Bulus Pesantren, dan Ambal). Sebanyak 100 peternak dipilih sebagai responden menggunakan metode pengambilan sampel secara berjenjang. Data dianalisis menggunakan statistik deskriptif dan Indeks Entropy Theil (IET) untuk menggambarkan tingkat perbedaan dalam potensi individu di antara peternak. Peternak sapi PO Kebumen memiliki potensi individu yang memadai dengan skor total 521,14. Perbedaan potensi individu antar peternak relatif tinggi $($ IET $=5,29)$. Secara parsial, ketimpangan peternak relatif tinggi dalam potensi penyediaan input $(6,06)$, potensi penyediaan tenaga kerja $(6,60)$ dan potensi dasar $(5,11)$. Fasilitas produksi ternak harus tersedia untuk menyeimbangkan potensi individu antar peternak dan mengurangi ketimpangan potensi individu antar peternak. Secara spasial upaya tersebut harus lebih di fokuskan pada wilayah pengembangan sapi PO Kebumen bagian barat.
\end{abstract}

Kata kunci: ketimpangan, potensi peternak, sapi PO Kebumen

\begin{abstract}
This research aimed to analyze the discrepancy in individual potential of Kebumen Ongole Grade cattle farmers, and analyze spatial grouping based on the farmers' individual potential. The study was conducted using survey method among cattle farmers in 6 districts which are the development centers of Kebumen Ongole Grade cattle in Kebumen Regency (District of Puring, Petanahan, Klirong, Mirit, Bulus Pesantren, and Ambal). One hundred Kebumen Ongole Grade cattle farmers were selected using multistage sampling method. The data were analyzed using descriptive statistics and Theil Entropy Index analysis to describe the level of discrepancy of farmers' individual potential. The cattle farmers have relatively sufficient individual potential with total score 521.14. Based on Theil Entropy Index, discrepancy in individual potential was relatively high (5.29). Partially, the cattle farmers' discrepancy was relatively high in the provision of production input (6.06), provision of work force potential (6.60), and basic potential (5.11). The production facilities need to be made available in order to accelerate farmers' individual potential and to reduce the discrepancy in individual potential among farmers. The western part of the cattle development area of Kebumen Regency must be given priority to realize the
\end{abstract}


uniformity of the potential of individual farmers.

Keywords: discrepancy, farmer's potential, Kebumen Ongole Grade cattle

\section{INTRODUCTION}

Since 2012, Kebumen Regency has been prioritizing on breeding farming system of Kebumen Ongole Grade cattle. The breeding farming system of Kebumen Ongole Grade cattle is progressing very rapidly in the technical and institutional manner with formation of 29 breeding groups in 6 districts, which are the breeding centers of Kebumen Ongole Grade cattle. Rohyan et al. (2016) stated that cow population of Kebumen Ongole Grade cattle in 2019 was estimated about 68,381 heads. Estimation of cow's population of Kebumen Ongole Grade cattle will increase 16.7 percent per year. In 2015, Kebumen Regency has been established as the region of source of Ongole Grade (PO) cattle breed with Decree of Minister of Agriculture of the Republic of Indonesia No. 47/ Kpts/SR.120/1/2015 dated January 16, 2015. Kebumen Regency had the opportunity to supply beef cattle continuously in order to fulfill the need for local, regional and national beef cattle.

Breeding farming system of Kebumen Ongole Grade cattle is still conducted in limited farm scale, where the farmers own 1-5 heads of cattle using simple technology utilization and management system. Technical and social efforts are conducted continuously with a touch of knowledge and technology to develop a stronger community-based in beef cattle development area. The availability of facilities and infrastructure for livestock becomes an important thing in strengthening the system and dynamics of beef cattle farming system. The quality of human resources and strong institution is urgently required to improve the efficiency and competitiveness of Kebumen Ongole Grade cattle farm. Farmers with adequate knowledge, skill and behavior capacities are the basic to strengthen community-based on beef cattle breeding system and rural economic development. Trauth (2012) stated that knowledge-based economy is the key for getting stricter competition. Innovation and human resource assets become important factors in winning economic sustainability and competition.

Improvement of human resource capacity is initiated with identification of livestock farmers' individual potential in rural area. Farmers' potential is the ability inherent in them and family support to develop the livestock farm. Farmers' potential is an important variable in the development and continuity of beef cattle farming (Direktorat Jenderal Bina Produksi Peternakan, 2003). The availability of livestock farmers' individual potential may be an important capital in effort to improve the productivity, strengthen the dynamics of business and secure the continuity of beef cattle farming. Teixeira (2014) explained Becker's theory with regard to human resource that human resource potential is very important in supporting of improvement of individual productivity. Discrepancy in human resource potential may inhibit the acceleration of productivity and economic performance of the business. Improved education, knowledge and technology mastery will enhance individual productivity. In the context of beef cattle farm, improved farm productivity may enhance farmers' family income. However, difference in individual characteristics, formal education and training, availability of production facilities may result in discrepancy in human resource potential.

Farmers' individual potential is one of the indicators to measure the quality of farmers' human resource, covering basic potential, technology mastery potential, work force potential and provision of production input potential. Lowitt et al. (2015) mentioned lack of financial, market, input, and knowledge of smallholder farmers are perceived as limiting farmers innovation potential. Discrepancy in farmers' individual potential may influence the acceleration of development of livestock, especially beef cattle breeding farming system. Success in identifying the discrepancy in farmers' individual potential will encourage strategies and efforts to improve the productivity and continuity of Kebumen Ongole Grade cattle farm.

This research aimed to (1) analyze the discrepancy in individual potential of Kebumen Ongole Grade cattle farmers, and (2) analyze spatial grouping based on Kebumen Ongole Grade cattle farmers' individual potential.

\section{MATERIALS AND METHODS}

The study of discrepancy and spatial grouping of individual potential among Kebumen 
Ongole Grade cattle farmers was conducted by survey method through interview using questionnaire and observation on one hundred (100) Kebumen Ongole Grade cattle farmers. The study was conducted in 6 areas of Kebumen Ongole Grade cattle development centers in Kebumen Regency. The research areas were selected purposively based on the production center of Kebumen Ongole Grade cattle (6 districts). The respondents were selected using multistage sampling method. In the first stage, 20 percent of the breeding groups were selected from each district. Moreover, 20 percent of the farmers were selected from each breeding group as respondent. The variables observed were basic potential, work load potential, provision of production input potential and technology mastery potential. The measurement of the variable refers to the Guidance for Individual Farmers Potential Analysis (Direktorat Jenderal Bina Produksi Peternakan, 2003). Individual potential of farmers $(\mathrm{M})=3 \mathrm{M}_{1}+4.5 \mathrm{M}_{2}+4 \mathrm{M}_{3}+5 \mathrm{M}_{4}$ which is $\mathrm{M}_{1}=$ basic potential, $\mathrm{M}_{2}=$ provision of work force potential, $\mathrm{M}_{3}=$ potential mastery of technology, $\mathrm{M}_{4}=$ provision of production inputs potential. Basic potential $\left(\mathrm{M}_{1}\right)$ includes livestock experience, formal education, non-formal education, the ability to read and write, and the intensity of communication. Provision of work force potential $\left(\mathrm{M}_{2}\right)$ includes number of family labor that can be used for livestock farm processes. Potential mastery of technology $\left(\mathrm{M}_{3}\right)$ includes the ability of farmers to choose and provide feed, the ability of farmers to treat livestock diseases, the ability of farmers to select the bull and cow. Provision of production input potential $\left(\mathrm{M}_{4}\right)$ includes the ability of farmers to provide production inputs in the form of ownership of housing, livestock and cash. The data were analyzed using descriptive statistics to describe the individual potential of Kebumen Ongole Grade cattle farmers and Theil Entropy Index (TEI) in order to describe the discrepancy in individual potential of Kebumen Ongole Grade cattle farmers. Sitepu et al. (2018) mentioned formula of Theil Entropy Index: $\mathrm{I}(\mathrm{y})=1 / \mathrm{N} \Sigma$ $(\mathrm{yj} / \mathrm{Y}) \times \log (\mathrm{yj} / \mathrm{Y}) /(\mathrm{xj} / \mathrm{X})$ which in this study was explained as I $(\mathrm{y})=$ Theil Entropy Index; $y j=$ individual potential of farmers in district $\mathrm{j} ; \mathrm{Y}=$ mean of individual potential of respondents in Kebumen Regency; $x j=$ number of respondents in district $\mathrm{j} ; \mathrm{X}$ : total number of respondents in Kebumen Regency, and N : number of districts.

Direktorat Jenderal Bina Produksi

Peternakan (2003) stated individual potential is categorized low when score is less than 436.91, moderate when score is 436.91-718.06, and categorized high when score is more than 718.06. Fussle (2005) mentioned the entropy index is a measure of difference and inequality that will explain how large the inequality and difference of variables from a group of respondents with values 0 to 1 (perfect difference). The values of entropy index measures vary between 0 and 1 , with zero representing an equal distribution and higher value representing a higher level of differences. Iglesias and de Almeida (2012) added the Theil Indices numerically represent a population's degree of dispersion with respect to a variable. Cluster analysis was used to describe the area grouping of Kebumen Ongole Grade development centers based on farmer's individual potential. Brauksa (2013) stated cluster analysis is one of statistical analysis that allows classifying observations in groups. Cluster analysis is often used because it can describe data into a dendogram graph.

\section{RESULTS AND DISCUSSION}

\section{Characteristics of Respondents}

Kebumen Ongole Grade cattle farmers are distributed in 6 districts which are the center of Kebumen Ongole Grade cattle development by involving 29 breeding farming groups. Table 1 describes the characteristics of Kebumen Ongole Grade farmers.

Table 1 describes that most of Kebumen Ongole Grade farmers (97\%) were in productive age (15-64 years old) and only $3 \%$ were in unproductive age ( $>64$ years old). Toluwase and Apata (2013) stated that productive age contributes to enhance productivity of agricultural activities. The existing knowledge, way of thinking, and skill during productive age can give a result in higher output for each unit of agricultural activity. Otieno et al. (2014) added that farmers' age influence enhancement of efficiency of beef cattle production.

Most of Kebumen Ongole Grade cattle farmers $(77 \%)$ graduate from high school and $23 \%$ had Elementary School' degree. Communitybased animal production is closely related to farmers' low level of education. Limited availability of economic assets, access to information, educational infrastructure, and poverty in rural area resulted in farmers and their family's low level of education. However, 
Table 1. Social and Economic Characteristics of Kebumen Ongole Grade Farmers

\begin{tabular}{lcc}
\hline \multicolumn{1}{c}{ Characteristics } & Total (people) & Percentage $(\%)$ \\
\hline Age (years) & 0 & 0 \\
Unproductive $(<15)$ & 97 & 97 \\
Productive $(15-64)$ & 3 & 3 \\
Unproductive $(>64)$ & & \\
Formal Education & 1 & 1 \\
None & 22 & 22 \\
Elementary School & 35 & 35 \\
Junior High School & 34 & 34 \\
Senior High School & 8 & 8 \\
University & & 2 \\
Farming Experience (years) & 2 & 18 \\
$<5$ & 18 & 80 \\
$5-10$ & 80 & 97 \\
$>10$ & & 3 \\
Number of Family Members & 97 & 2 \\
$\leq 4$ & 3 & 98 \\
$>4$ & & \\
Number of Cattle (Animal Units) & 98 & \\
$<4$ & 2 & \\
$\geq 4$ & & \\
\hline
\end{tabular}

Kebumen Ongole Grade cattle farmers are dominated by productive-aged farmers with education graduated from high school. Isyanto et al. (2013) stated that education has significant impact on the improvement of efficiency of beef cattle farming. Mor and Sharma (2012) added that highly educated farmers will be able to accept, intercept and respond to new information and adopt the technology better than low educated farmers. Burger and Teal (2014) emphasized the importance of formal education to enhance work productivity. It mentioned that farmers who are having higher formal education will enhance their working productivity.

Kebumen Ongole Grade cattle farmers do not run cattle production for only economic orientation, but it has been being their hereditary way of life. Most of the farmers (80\%) had experienced for more than 10 years in beef cattle farming even if it is in limited number of cattle.
Nwigwe et al. (2016) stated that the efficiency of animal production might be enhanced for farmers with longer experience in beef cattle farming. Beef cattle farming experience is a medium to accelerate the efficiency of production technology.

Beef cattle farming of Kebumen Ongole Grade is conducted in small scale production unit which most of the farmers (98\%) had less than 4 Animal Units. The small-scale farming system was caused by limited farm capital and livestock farming system as a side job. Bhatt and Bhat (2014) stated that the small size number of livestock is the main reason of low farm efficiency. With regard to income, Mabe et al. (2010) stated that the enhancement of livestock farming income is closely related to the number of cattle they raise. Increase in the number of livestock may boost an increase of cattle farming income. 


\section{Discrepancy in Farmers' Individual Potential}

Farmers' potential is the ability inherent in the farmers and family support to develop their livestock farm. Farmers' potential is an important indicator in beef cattle raising farm. Farmers' individual potential is the accumulation of farmers' basic potential, work force potential, technology mastery potential and provision of production input potential (Direktorat Jenderal Bina Produksi Peternakan, 2003).

Kebumen Ongole Grade cattle farmers had moderate individual potential with a mean score of 521.14. Farmers' individual potential was in moderate category within interval range of score of 436.91-718.06. Kebumen Ongole Grade cattle farmers had high technology mastery potential (score 17.15) including ability of farmers to choose and provide feed, the ability of farmers to treat livestock diseases, the ability of farmers to select the bull and cow. The artificial insemination technology and livestock feed technology encouraged the farmers to improve their Kebumen Ongole Grade cattle breeding pattern using artificial insemination. On the other hand, Kebumen Ongole Grade cattle farmers had high basic potential including formal education, nonformal education, livestock raising experience and communication intensity aspects. Suroto and Nurhasan (2014) stated that farmers' basic potential and technology mastery have better influence in the development of beef cattle farming system. Sugiarto and Nur (2013) confirmed that if the farmers are able to improve their individual potential, it may enhance the efficiency of animal production farm. Table 2 shows the discrepancy in individual potential of Kebumen Ongole Grade cattle farmers.

The availability of farmers with high potential becomes an important capital in the development of Kebumen Ongole Grade cattle farm. Isaksen (2006) stated that individual with higher human resource capital can be skillful and more competent to manage production process with high productivity system. However, discrepancy in farmers' individual potential in an area may decrease the technical and economic performance of Kebumen Ongole Grade farming system as a whole. Relatively equal level of individual potential between farmers within breeding groups will accelerate the growth of Kebumen Ongole Grade cattle farm. Theil Entropy Index was used to measure discrepancy between groups in income aspect and other aspects. Militaru and Stanila (2015) stated that Theil Entropy Index measuring the level of inequality of group which includes some social and economic characteristics. Reardon and Firebaugh (2002) added concept of entropy to the social sciences is used as a measure of population diversity

Based on Theil Entropy Index analysis, it found that technology mastery potential of farmers was relatively more homogenous than farmers' basic potential, provision of work force potential and provision of production input potential. Technology mastery potential includes knowledge of feed technology, disease prevention and livestock selection. The relatively low discrepancy in technology mastery (2.96) was caused by adequate farmers' ability to manage cattle breeding. The introduction of animal feed technology and artificial insemination has been able to encourage farmers to use improved breeding patterns. In addition, technological extension services and institutional counseling had been conducted by government and extension

Table 2. Discrepancy in Individual Potential of Kebumen Ongole Grade Farmers

\begin{tabular}{lrlc}
\hline \multicolumn{1}{c}{ Farmers' Potential Variable } & Mean & Category & $\begin{array}{c}\text { Theil Entropy Index } \\
\text { (TEI) }\end{array}$ \\
\hline Basic Potential & 101.11 & High & 5.11 \\
Work Force Potential & 7.50 & Low & 6.60 \\
Technology Mastery Potential & 17.15 & High & 2.96 \\
Provision of Production Input Potential & 23.46 & Low & 6.06 \\
Individual Potential & 521.14 & Medium & 5.29 \\
\hline
\end{tabular}


agents might equalize knowledge and technology mastery among farmers. Houessou, et al. (2019) stated intervention from the government and extension workers can maintain the production system through increasing adoption of various production technologies and access to market, finance and health services.

Kebumen Ongole Grade cattle farmers showed high diversity in the provision of work force for beef cattle farming system. The provision of work force potential was the structure of available work load in the family and the number of work force in the family used for Kebumen Ongole Grade cattle farming system. The high discrepancy in the provision of work force is shown by Theil index of 6.60. It was caused by variation in number of family members work in beef cattle farming system and only 1 person from a family member who participates in a livestock farm due to limited number of farm size.

The provision of production input potential showed relatively significant discrepancy among the Kebumen Ongole Grade cattle farmers (6.06). The provision of production input included housing ownership, livestock ownership, and ability to provide cash. Farmers' main job other than beef cattle farm can be differentiator in the control of farmers' asset, including the number of livestock, housing and farm capital. Kebumen Ongole Grade cattle farmers have varied main jobs from farmworker to government employee and private sectors. Lopez (2008) stated that the ownership of livestock and other physical assets has a real impact on the improvement of farm income. Income earned from non-beef cattle farming activity was likely to be the main salary to support beef cattle farming activities.

The basic potential of farmers also showed a fairly wide discrepancy (5.11). The basic potential of farmers includes experience in cattle farming, formal education, non-formal education / training, reading and writing skills and the intensity of communication. The wide discrepancy of farmers' basic potential is due to the heterogeneity of experience in farming and the intensity of communication between farmers. Differences in farming experience and intensity of communication can be the cause of weak information and knowledge possessed by farmers. Siriwardhana and Jayawardena (2014) stated that farmers' knowledge in the development of business, innovation and creativity were closely related to farmer' farming experience.

\section{Spatial Grouping Based on Farmers' Individual Potential}

Kebumen Ongole Grade cattle is developed in Urut Sewu, Kebumen Regency including District of Mirit, Ambal, Bulus Pesantren, Klirong, Petanahan and Puring. The farmers breed the cattle in each area with different type and level of ability, individual potential and problem.

Human resource development is very important in livestock development, especially Kebumen Ongole Grade cattle. The discrepancy in some aspects of farmers' individual potential must be taken into consideration by the policy makers in Kebumen Regency. In addition, the specific policy formulation can be implemented based on farmers' real condition in every areas.

Cluster analysis was a method used for area grouping of Kebumen Ongole Grade development centers in Kebumen Regency. Saputra et al. (2016) stated that cluster analysis is one of double variable analysis that aims to classify groups or objects into some clusters based on similarity of observed variable, thus the similarity is obtained for objects within the same cluster compared to objects from different cluster. The grouping method that may be used in hierarchical cluster analysis is single linkage method. Cluster analysis was used to clasify group areas of Kebumen Ongole Grade cattle development center based on the characteristics of basic potential, provision of work load potential, technology mastery potential and provision of input production. Grouping was initiated by identifying the mean score of those potentials in each district (Kebumen Ongole Grade cattle development center). Table 3 shows the score farmers' individual potential in 6 development areas of Kebumen Ongole Grade cattle.

In further stage, the data were clustered, involving 6 objects of Kebumen Ongole Grade cattle development area. The clustering process would finally combine the objects based on the characteristic similarity of basic potential, provision of work force potential, technology mastery potential and provision of production input potential. The following grouping of development areas is presented in Table 4.

Based on cluster membership group, farmers in cluster 1 (Mirit, Ambal and Klirong Districts) have relatively better farmers' individual potency than farmers in cluster 2 (Bulus Pesantren, Petanahan and Puring Districts). Moreover, the performance of discrepancy among six groups of development area of Kebumen Ongole Grade can 
Table 3. Score Farmers' Individual Potential in 6 Development Areas of Kebumen Ongole Grade Cattle

\begin{tabular}{lccccc}
\hline \multicolumn{1}{c}{ District } & Basic Potential & $\begin{array}{c}\text { Provision of Work } \\
\text { Force Potential }\end{array}$ & $\begin{array}{c}\text { Technology } \\
\text { Mastery } \\
\text { Potential }\end{array}$ & $\begin{array}{c}\text { Provision of } \\
\text { Production } \\
\text { Input Potential }\end{array}$ & $\begin{array}{c}\text { Farmers' } \\
\text { Individual } \\
\text { Potential }\end{array}$ \\
\hline Mirit & 105.6 & 6.80 & 17.34 & 33.53 & 587.84 \\
Ambal & 101.5 & 7.24 & 16.25 & 33.61 & 560.02 \\
Bulupesantren & 99.8 & 4.32 & 16.67 & 20.56 & 503.16 \\
Klirong & 102.0 & 6.20 & 17.16 & 27.07 & 536.01 \\
Petanahan & 99.06 & 3.97 & 17.81 & 19.99 & 510.91 \\
Puring & 101.9 & 2.49 & 17.46 & 15.13 & 492.83 \\
\hline
\end{tabular}

Table 4. Cluster Membership of Kebumen Ongole Grade Cattle Development Area

\begin{tabular}{lc}
\hline \multicolumn{1}{c}{ (Name of District) } & $\begin{array}{c}\text { Farmers' Individual } \\
\text { Potential Score }\end{array}$ \\
\hline Cluster 1: & \\
Mirit & 587.84 \\
Ambal & 560.02 \\
Klirong & 536.01 \\
Cluster 2: & \\
Petanahan & 510.91 \\
Buluspesantren & 503.16 \\
Puring & 492.83 \\
\hline
\end{tabular}

be described in the dendrogram graphic. Schonlau (2002) explained dendrogram is a graph used to visualize how clusters are formed. The horizontal axis of the dendrogram represents the distance or dissimilarity between clusters. The vertical axis represents the objects and clusters. Figure 1 shows the spatial grouping of Kebumen Ongole Grade cattle development center using dendrogram.

Based on the dendrogram graphic, Bulus Pesantren and Petanahan Districts have high uniformity, followed by Mirit and Ambal Districts. Furthermore, in the bigger group, Bulus Pesantren, Petanahan and Puring cluster also have high uniformity/similarity than other clusters. The high uniformity result was caused by the similarity of extension program in every area, artificial insemination, feeding management, for instance. Based on cluster analysis, the area of development of Kebumen Ongole Grade cattle is divided into 2 clusters based on individual potential of farmers. Cluster 1 includes the eastern part of Kebumen Regency (Mirit, Ambal and Klirong Districts) having the uniformity of individuals potential with a higher category than cluster 2 namely the western part of Kebumen Regency (Puring, Petanahan and Bulus Pesantren Districts). Making the strengthening of farmers' human resources as the cornerstone of increasing productivity, The Office of Agriculture and Food of Kebumen Regency must give priority to areas in cluster 2 that have relatively lower potential individual farmers. The production facilities especially in western area of development center of Kebumen Ongole Grade cattle need to be made available in order to accelerate farmers' individual potential and to reduce the discrepancy in individual potential among farmers. It need also to improve capacity of the extension agents through training and communication skill in order to establishing trust and sharing with the farmers.

\section{CONCLUSION}

The Kebumen Ongole Grade cattle farmers have sufficient individual potential even though the discrepancy of Kebumen Ongole Grade cattle farmers' individual potency is relatively high. The discrepancy of individual potency is caused by discrepancy in basic potential, work force potential and provision of production input potential. The development area of the Kebumen Ongole Grade is divided into 2 clusters based on 


District
Buluspesantren
Petanahan
Puring
Ambal
Klirong
Mirit

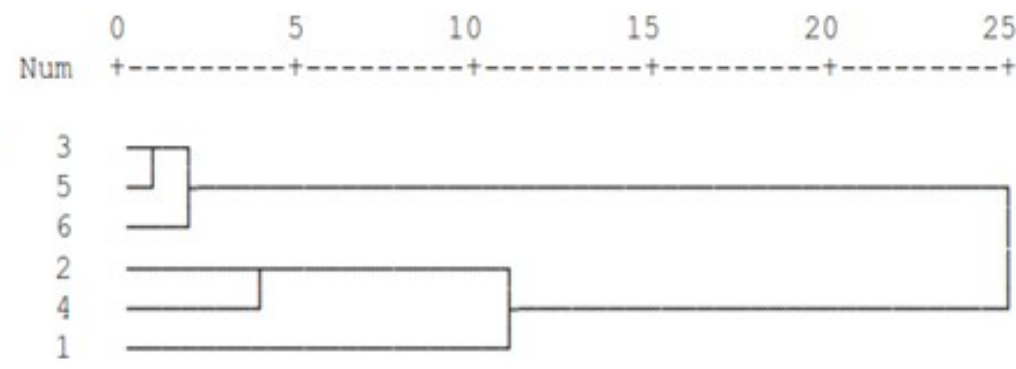

Figure 1. Spatial Grouping of Kebumen Ongole Grade Cattle Development Center Using Dendrogram

the individual potential of farmers. The eastern part of Kebumen Regency (Mirit, Ambal, Klirong Districts) composed cattle farmers with relatively higher individual potential than farmers in the western part of Kebumen Regency (Puring, Petanahan and Bulus Pesantren Districts).

\section{REFERENCES}

Bhatt, M.S. and S. Ahmad Bhat. 2014. Technical efficiency and farm size productivity-micro level evidence from Jammu and Kashmir. Int. J. Food Agric. Econ. 2:27-49.

Brauksa, I. 2013. Use of cluster analysis in exploring economic indicator differences among regions: The case of Latvia. Journal of Economics, Business and Management. 1(1): 42-45

Burger, R. P. and F. J. Teal. 2014. The Effect of schooling on worker productivity: Evidence from South African Industry Panel. CSAE Working Pper Series 2014-10, Centre for the Study of African Economies, University of Oxford.

Direktorat Jenderal Bina Produksi Peternakan, 2003. Pedoman Analisis Potensi Peternak.

Ditjen Bina Produksi Peternakan. Departemen Pertanian. Jakarta.

Fussel, E. 2005. Measuring the early adult life course in Mexico: An application of the Entropy Index. Advances in Life Course Research. 9: 91-122.

Houessou, S.O., L.H. Dossa, R.V.C. Diogo, M. Houinato., A. Buerkert., and E. Schlecht. 2019. Change and continuity in traditional cattle farming systems of West African Coast countries: A case study from Benin. Agricultural Systems 168:112-122.
Iglesias, J. R., and R.M.C. de Almeida. 2012. Entropy and equilibrium state of free market models. Eur. Phys. J. B. 85:1-10

Isaksen, E. J. 2006. Early Business Performance: Initial Factors Effecting New Business Outcomes, $\mathrm{PhD}$ Series, No. 6, Bodo Graduate School of Business. Norway.

Isyanto, A.Y., M.S. Ikhsan, Nuhfil H. and Syafrial. 2013. Measurement of farm level efficiency of beef cattle fattening in West Java Province, Indonesia. Journal of Economics and Sustainable Development. 4: $100-104$.

Lopez, R.S. 2008. Livelihood strategies in Bolivar, Ecuador: Asset distribution activity selection and income decisions in rural households. Thesis Report. Virginia Polytechnic and State University, Blacksburg Virginia.

Lowitt, K., G.M. Hickey. T. Thompson-Colo. S.L. Arletette and L.E. Phillip. 2015. Factors affecting the innovation potential of smallholder farmers in the Caribbean Community. Reg Environ Change. 15:13671377.

Mabe, L.K., M.A. Antwi and O.I. Oladele. 2010. Factors influencing farm income in livestock producing communities of NorthWest Province, South Africa. Livestock Research for Rural Development. 22(8). Paper 142.

Militaru, E and L. Stanila. 2015. Income variability in Romania: Decomposing income inequality by household characteristics. Procedia Economics and Finance. 26:227-233

Mor, S. and S. Sharma. 2012. Technical efficiency and supply chain practices in dairying: The 
case of India. Agric. Econ. 58:85-91

Nwigwe, C., V. Okoruwa, K. Adenegan and A. Olajide. 2016. Technical efficiency of beef cattle production technologies in Nigeria: A Stochastic Frontier Analysis. Afr. J. Agric. Res. 11:5152-5161

Otieno, D. J., L. Hubbard and E. Ruto. 2014. Assessment of technical efficiency and its determinants in beef cattle production in Kenya. J. Dev. Agric. Econ 6: 267-278.

Reardon, S.F. and G. Firebaugh. 2002. Measures of multigroup segregation. Sociol Methodol. 32:33-67

Rohyan, J., Sutopo., and E. Kurnianto. Population dynamics on Ongole Grade Cattle in Kebumen Regency - Central Java. J. Indonesian Trop. Anim. Agric. 41(4):224232

Saputra, D., N. Satyahadewi and N. N. Debataraja. 2016. Pengelompokan kabupaten/kota di Kalimantan Barat berdasarkan indikator dalam pemerataan pendidikan menggunakan metode minimax linkage. Buletin Ilmiah Mat. Stat. dan Terapannya (Bimaster). 5:253 - 260.

Schonlau, M. 2002. The Clustergram: A graph for visualizing hierarchical and non-hierarchical cluster analyses. STATA J. 3: 316-327

Siriwardhana, A.N and L.N.A.C. Jayawardena. 2014. Socio-demographic factors contributing to the productivity in paddy farming: A case study. Trop. Agric. Res. 25(3):437-444

Sitepu, H.R., O.Darnius, W.N.Tambunan.2018. Regional income inequality model based on theil index decomposition and weighted variance coefficient. J. Physics: Conf. Series 983:1-6

Sugiarto, M and S.Nur. 2013. Pengembangan potensi sumberdaya peternak sebagai upaya peningkatan daya saing peternakan kambing skala mikro di Kabupaten Banyumas. Proceedings Seminar Nasional Sustainable Competitive Advantage (SCA-3). Fakultas Ekonomi dan Bisnis Unsoed, Purwokerto. November 1, 2013. P. 262-267.

Teixeira, P.N. 2014. Gary Becker's early work on human capital - collaborations and distinctiveness. IZA Journal of Labor Economics. 3 (12): 1-20

Toluwase, S.O.W and O.M. Apata. 2013. Impact of farmers' cooperative on agricultural productivity in Ekiti State, Nigeria. Greener J. Agric. Sci.. 3(1):063-067.

Trauth, E. M. 2012. Barriers to knowledge acquisition, transfer and management in regional knowledge economy development. Proceedings, the 45th Hawaii International Conference on System Sciences. P.36123621. 